\title{
Copper Deposits of the Prince William Sound District, Alaska
}

By FRED H. MOFFIT and ROBERT E. FELLOWS

MINERAL RESOURCES OF ALASKA, 1945-46, p p. 47-79

GEOLOGICAL SURVEY BULLETIN 963-B

An account of the present state of the prospects, extent of development, and condition of equipment

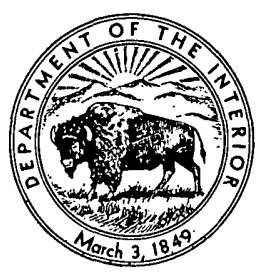


UNITED STATES DEPARTMENT \OF THE INTERIOR

Oscar L. Chapman, Secretary

GEOLOGICAL SURVEY

W. E. Wrather, Director

For sale by the Superintendent of Documents, U. S. Government ${ }^{\text {Printing Office }}$ Washington 25, D. C. - Price 75 cents (paper cover) 


\section{CONTENTS}

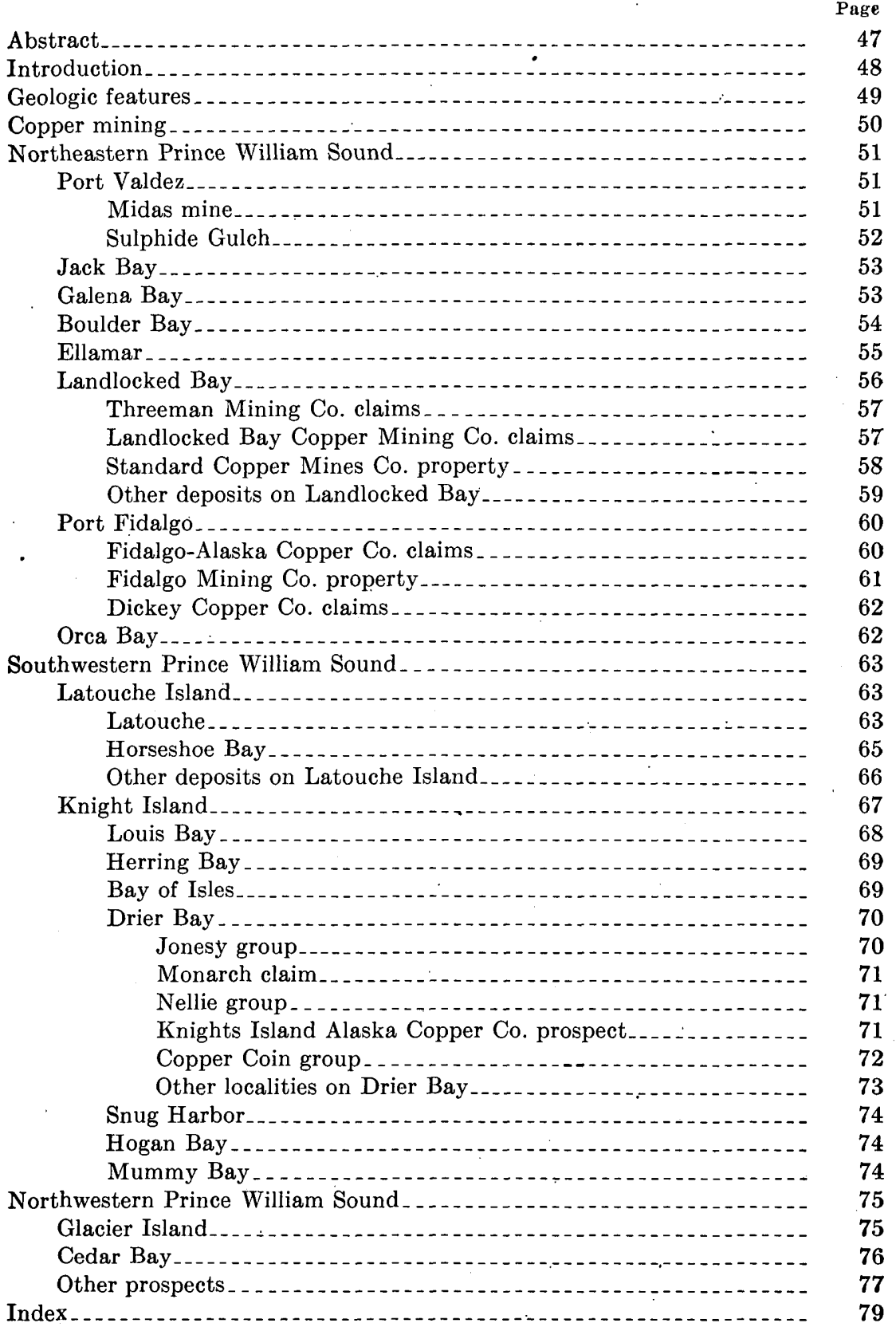




\section{ILLUSTRATIONS}

Plate 3. Map of Prince William Sound, Alaska_- In pocket

4. Map of northeastern Prince William Sound_.._._._._...... In pocket

5. Map of southwestern Prince William Sound___-_._-_._-_.- In pocket

6. Map of northwestern Prince William Sound_____._._... In pocket

Figure 20. Sketch map of Alaska showing location of Prince William

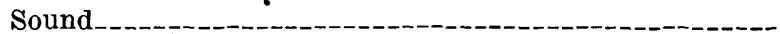




\title{
COPPER DEPOSITS OF THE PRINCE WILLIAM SOUND DISTRICT, ALASKA
}

\author{
By Fred H. Moffit and Robert E. Fellows
}

\begin{abstract}
The purpose of this paper is to review the copper deposits of the Prince Wlliam Sound district of Alaska and in particular to give an account of the present state of the copper prospects, including the extent of development work done and the condition of the equipment. This district is no longer productive although in past years it included important copper mines. The field work on which the report is based involved visiting most of the better known deposits of Prince

- William Sound. These deposits are associated more or less with greenstone lava flows and intrusives that are interbedded with the slate and graywacke of the Sound area, although they are not confined to them, and are grouped in three principal areas: the northeastern part of the Sound from Valdez Bay to Port Fidalgo; Latouche and Knight Islands of southwestern Prince William Sound; and part of the northwestern Prince William Sound, particularly Glacier Island and some of the neighboring mainland.

The general investigation of the Sound area was supplemented by a special study, including underground and surface mapping, of the copper deposits at Rua Cove on the east side of Knight Island.

The copper deposits of northeastern Prince William Sound include the mine at Ellamar, and several smaller mines that shipped significant quantities of ore. Among the latter are the Midas mine near Valdez, the Threeman mine on Land-

' locked Bay, and the Fidalgo-Alaska mine on Port Fidalgo, besides a number of others each of which produced a few tons of copper.

The Beatson-Bonanza mine at Latouche yielded more copper than any other deposit at Prince Wiliam Sound. Its output was several times that of Ellamar and, combined with the latter, accounted for more than 96 percent of the copper shipped from the mines of the district during the period of sustained production that began shortly after 1900 and ended when the mines at Latouche were closed in 1930.

Although Knight Island afforded a large number of copper prospects, some of which yielded small quantities of shipping ore, it has no important mine, and, with the possible exception of the large low-grade copper deposit of Rua Cove, it has no known copper prospects that are likely to be dereloped into mints. The other best-known prospects are on Louis Bay, the Bay of Isles, Drier Bay, Snug Harbor, Hogan, and Mummy Bays, all places at which considerable development work has been done.

The mineralized rock on northwestern Prince William Sound is different from that of most of the Sound area, and it has received more attention for its gold
\end{abstract}


than for its copper. However, considerable development work was done on copper deposits in the greenstone area of Glacier Island, at Cedar Bay, and at neighboring localities. The deposits of Cedar Bay contain a greater proportion of zinc than of copper and have been considered as a possible source of that metal.

\section{INTRODUCTION}

Prince William Sound, on the south-central coast of Alaska (pl. 3; fig. 20), was a producing mining district for many years and yielded

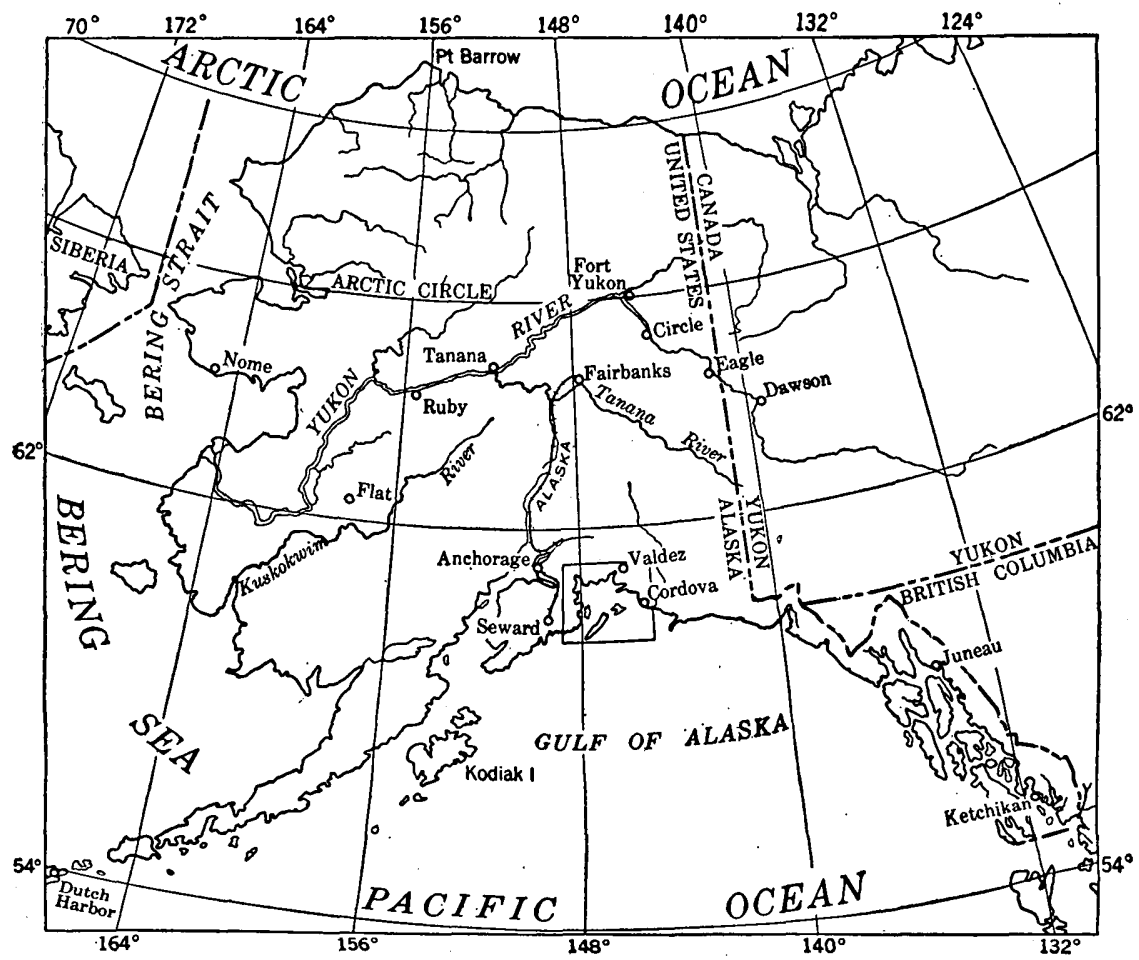

Figure 20.- Sketch map of Alaska showing location of Prince William Sound.

both copper and gold in important amounts. The first copper deposit discovered on Prince William Sound is said to be one on Landlocked Bay ${ }^{1}$ that was staked in 1897 and was known as the Alaska Commercial Co.'s property. Interest in prospecting for copper grew rapidly and was at its highest about 1907. At that time many men were engaged in the search for copper deposits and many claims were staked, especially on Knight Island and in the vicinity of Ellamar and on Port Fidalgo. Sporadic interest has been shown since that time, but no production has been reported in the area since 1930 .

\footnotetext{
1 Capps, S. R. and Johnson, B. L., The Ellamar district, Alaska : U. S. Geol. Survey Bull. 605, p. 107, 1915.
} 
Most of the copper deposits of Prince William Sound are grouped in two major areas (see pls. 4 and 5) that include Port Valdez, Ellamar, Landlocked Bay, and Port Fidalgo on the northeast and Latouche and Knight Island on the southwest. Additional deposits are plotted on plate 6. This distribution is in accord with that of the larger areas of greenstone, which represents altered lava flows. Other deposits were found on Glacier Island and in the vicinity of Cordova, where they are also in areas of greenstone. In addition, copper minerals are present at several localities in the north part of the Sound area far from known greenstone although in the vicinity of intrusive bodies of granitic rock. The copper minerals commonly are associated with small quantities of sulfide minerals, such as sphalerite and galena, and with gold. A few of the deposits are of interest because of minerals other than those of copper.

The published descriptions of copper deposits and mining development on Prince William Sound by earlier investigators have been used freely in preparing this report and are referred to in the appropriate places. The published reports have been supplemented by the field work of the senior author in 1923-25 and of both authors in 1943. Mr. Fellows was responsible for reviewing the literature, making thinsection analyses, and studying polished specimens of ores. Much more detailed information about many of the mines and prospects will be found in the early reports. The general descriptions by the United States Geological Survey that will be found most useful are the published reports of Grant and Higgins, ${ }^{2}$ Capps and Johnson, ${ }^{3}$ and Johnson. ${ }^{4}$

\section{GEOLOGIC FEATURES}

Prince William Sound is at the extreme northern limit of the Gulf of Alaska and extends far into the heart of the coast range or Chugach Mountains. It has a long and intricately indented shore line and

\footnotetext{
${ }^{2}$ Grant, U. S. and Higgins, D. F., Reconnaissance of the geology and mineral resources of Prince William Sound, Alaska : U. S. Geol. Survey Bull, 443, 1910. .

${ }^{3}$ Capps, S. R. and Johnson, B. L., The Ellamar district, Alaska: U. S. Geol. Survey Bull. 605,1915 .

${ }^{4}$ Johnson, B. L., The Port Wells gold-lode district, in Mineral Resources of Alaska, 1913 : U. S. Geol. Survey Bull. 592, pp. 195-236, 1914; Mining on Prince William Sound, in Mineral Resources of Alaska, 1913: U. S. Geol. Survey Bull. 592, pp. 237-243, 1914; Mining on Prince William Sound, in Mineral Resources of Alaska, 1914: U. S. Geol. Survey Bull. 622, pp. 131-139, 1915; The gold and copper deposits of the Port Valdez district, in Mineral Resources of Alaska, 1914 : U. S. Geol. Survey Bull. 622, pp. 140-188, 1915 ; MinIng on Prince William Sound, in Mineral Resources of Alaska, 1915: U. S. Geol. Survey Bull. 642, pp. 137-145, 1916; Mining on Prince William Sound, in Mineral Resources of Alaska, 1916 : U. S. Geol. Survey Bull. 662, pp. 183-192, 1918; Copper deposits of the Latouche and Knight Island districts, Prince William Sound, in Mineral Resources of Alașka, 1916: U. S. Geol. Survey Bull. 662, pp. 193-220, 1918 ; Mining on Prince William Sound, in Mineral Resources of Alaska, 1917 ; U. S. Geol. Survey Bull. 692, pp. 143-151, 1919 ; Mineral Resources of Jack Bay district and vicinity, Prince William Sound, in Mineral Resources of Alaska, 1917 : U. S. Geol. Survey Buil. 692, pp. 153-173, 1919.
} 
many islands. Both the mainland and the islands are characterized by high relief and the absence of relatively level lowland areas other than the narrow flood plains of some of the larger streams. Much of the mountain area is above the level of perpetual snow; many valleys are occupied by glacial ice, which descends to the sea.

The rocks of Prince William Sound are chiefly interbedded slate and graywacke, with which are associated basaltic lava flows and beds of conglomerate, sandstone, and limestone in notably minor amount. These rocks are folded and faulted and have been invaded in places by dikes, sills, and larger irregularly shaped bodies of lightcolored igneous rocks that include granite and related intrusives. Although these rocks are severely folded they are not greatly altered and are not generally schistose. The total thickness of the sedimentary beds is unknown but evidently it is to be measured in thousands of feet. The age of the rocks also is not definitely known but all the sedimentary deposits are now considered to be probably of Mesozoic age, and certain beds on the north side of the sound are assigned to the Cretaceous with a high degree of probability.

The greenstones are of particular interest because the copper deposits are so distributed as to indicate an almost certain genetic relationship. The greenstones are dark basaltic rocks that commonly show a well-developed pillow structure. This structure and other evidence, such as interbedded lenses of shale, indicate that most of the lava flows were poured out under water and deposited contemporaneously with certain of the sediments. Greenstones are present in different parts of the Sound but have their greatest areal development on Knight Island and on other nearby islands to the southwest. All the known copper deposits of possible commercial importarice are within or near areas of greenstone.

\section{COPPER MINING}

The mining of copper on Prince William Sound began almost as soon as copper deposits were discovered. The early shipments to the smelter were small and included only high-grade ores, those averaging about 10 percent of copper. Many prospects produced only a few tons, of which no specific record is available, but which altogether amounted to only a very insignificant quantity in relation to the total production of the district. Sustained production began at Ellamar and Latouche, which were staked in 1897, and ended with the closing of the Kennecott Copper Corp. mines at Latouche in 1930.

In the years from 1900 to 1930 nearly $214,000,000$ pounds of copper were produced by 15 operating companies. Of this quantity, more than 96 percent was produced at Latouche and Ellamar by the Beatson Copper Co. (Kennecott) and the Ellamar Mining Co. Among the 15 
companies referred to and in addition to the two companies just mentioned, three companies-the Fidalgo-Alaska Copper Co., the Midas Copper Co., and the Threeman Mining Co.-each produced more than one million pounds of copper.

\section{NORTHEASTERN PRINCE WILLIAM SOUND PORT VALDEZ \\ MIDAS MINE}

The Midas mine in Solomon Gulch on the south side of Port Valdez, a few miles south of the town of Valdez, is one of the formerly productive mines of Prince William Sound. (see pl. 4.) The mine is the property of the Granby Consolidated Mining, Smelting \& Power Co., Ltd., but it had passed through various ownerships before it was acquired by that company.

Solomon Gulch is the valley of a stream some eight miles long that furnishes part of the light and power for Valdez. The mine is near the head of the valley and is connected with the beach by a wagon road and trail. In addition to the necessary buildings for housing and feeding men and protecting machinery and supplies at the mine and at the beach, the mine was equipped with an aerial tram $51 / 4$ miles long. The tram carried ore from the mine to a bunker at the shore of the bay where it was loaded on ships and taken to the smelter at Anyox in British Columbia. For about 5 years these facilities were in use, but in 1920 shipping conditions were such that steamship transportation for ore was not available. Accordingly, operations were ended in the fall of that year, and they have not been resumed. In 1943 the bunker which was of exceptionally good construction was torn down in order to salvage the timbers with which it was built. The approach to the bunker from the shore and all untreated piling had already been destroyed by the waves and teredos, and the tramline had been removed. The buildings at the mine also are in such poor condition that practically the whole installation must be replaced if mining is resumed.

The claims of the Midas property include two ore bodies known as the Jumbo and the All-American lodes. The Jumbo lode is the principal deposit and was the source of the ore shipped to the smelter. The ore occurs in mineralized shear zones in rocks that are dominantly black slate intruded by small bosses, sills, and dikes of greenstone. Argillites, cherts, graywackes, and quartzites are associated with the slates. All are intensely deformed and have schistose phases.

The ore body was exploited from four adit levels, spaced at intervals of 67,157 , and 290 feet from the lowest level or level 4 . A raise was driven from the lowest level to a point above level 2 and a 
shaft was sunk from level 2 to a depth of 200 feet below level 4. Ore was mined from stopes between the second and fourth levels in a shear zone that dips north at angles ranging from $30^{\circ}$ to $70^{\circ}$ and from included ore shoots pitching to the west. The highest adit was on a separate ore body.

The ore-bearing shear zone of the Jumbo lode ranges from a few inches to 20 feet in thickness but averages between 3 and 4 feet. It strikes about west and has been traced horizontally for 800 feet in the underground workings.

The All-American lode is about one-half mile south of the Jumbo lode. It is said to be wider and of lower grade than the Jumbo lode. It is a sulfide-impregnated shear zone in sedimentary rocks on the north side of a greenstone intrusive mass; like the Jumbo lode it strikes approximately west and dips to the north. It has been explored by open-cuts and some underground openings.

According to Johnson ${ }^{5}$

The ores [of the Jumbo and All-American lodes] are partly replacements and impregnations of the crushed country rocks and partly the result of cementation of small fractures by the ore minerals. The sulphide minerals present are pyrite, chalcopyrite, pyrrhotite, and sphalerite. Abundant beds of fine-grained pyrite are found in places. A little quartz is associated with the sulphides, and in the driving of the lower tunnel on the Jumbo lode lenses of quartz which had a maximum thickness of 1 foot were encountered. Sulphide-bearing quartz stringers are also reported to occur along the footwall of the shear zone on this lode. Gold and silver are reported in assays of the ores, but neither metal has been observed in specimens. Some limonite has resulted from the surficial oxidation of the iron-bearing sulphides, and malachite stains from the carbonation of the chalcopyrite.

The Midas mine, which has been idle for many years, appears to have been closed because of difficulties arising in connection with the transportation of the ore from Valdez to the smelter rather than from exhaustion of the ore bodies. It may be looked on as one of the possible sources of copper in Prince William Sound although the disposal of the ore bunker does not suggest that the owners regard it as such.

SULPHXDE GULCH

A large low-grade copper prospect that was explored in former years is in Sulphide Gulch southeast of Valdez (pl. 4). Sulphide Gulch is a southern tributary of Lowe River, and the copper deposit is about 4 miles from its mouth.

The prospect was long known as the Addison Powell property, and at the time when described by Johnson ${ }^{6}$ it was owned by the Peabody

J Johnson, B. L., Mineral resources of Jack Bay and vicinity, Prince William Sound. In Mineral Resources of Alaska, 1917 : U. S. Geol. Survey Bull. 692, p. 170, 1919.

Johnson, B. L., Mining on Prince Wiliam Sound, in Mineral Resources fo Alaska, 1915 : U. S. Geol. Survey Bull. 642, p. 140 1916; U. S. Geol. Survey Bull. 662, p. 185, 1918. 
Alaska Copper Corp. At that time the development was reported to include open-cuts, stripping, and more than 100 feet of tunneling. The principal copper mineral in the ore is chalcopyrite. Recent development work on this property has not been reported.

\section{JACK BAY}

Several showings of copper minerals ${ }^{7}$ were found on Jack Bay south of Port Valdez (pl.4), and were of such promise as to encourage exploration. One of the showings is on the north side of Jack Bay about 2 miles from the entrance and 600 feet above sea level. A shear zone in the graywacke country rock strikes N. $10^{\circ}$ E. and dips $70^{\circ} \mathrm{W}$. A tunnel was driven about 4.0 feet into the shear zone at the foot of a bluff where the zone shows a width of 2 to 4 feet and is slightly mineralized. The mineralized rock contains the sulfides arsenopyrite, chalcopyrite, pyrrhotite, sphalerite, and galena. No recent work on the tunnel has been reported.

A second showing of copper minerals is on the north side of the south arm of Jack Bay about a mile from the point of land between the two arms. The country rock is interbedded slate and graywacke, which is intruded by a small body of greenstone. Inclusions of the sedimentary rocks in the greenstone are slightly metamorphosed and mineralized with the sulfides pyrite, pyrrhotite, chalcopyrite, and sphalerite accompanied by a little quartz. The showing was staked and explored by a 25 -foot tunnel near the beach, but no ore body was developed.

\section{GALENA BAY}

Extensive exploration for copper in the Galena Bay area (pl. 4) was carried on by the Galena Bay Mining Co. in the years from 1905, when their operations began, to 1914 when the claims were surveyed for patent. The claims are in upper Vesuvius Valley about 3 miles south of the head of Galena Bay and cover widely separated ore deposits.

Development work was done on all of the claims. The equipment included four dwelling houses, a bunkhouse, and storehouse at the beach, a wagon road from the bay to the camp at the principal tunnel, 900 feet above the bay, and seven buildings at the camp, together with considerable mining machinery. A log dam across Bottle Creek at a point three-fourths of a mile from the bay furnished power for electric drills and several motors and for lighting for the camp. Material for an aerial tram was placed on the ground but was never erected. Most of the castings were not taken from the boxes in which they were shipped and remain where they were distributed along the road. The cable and some of the electrical machinery were sold after

${ }^{7}$ Johnson, B. L., Mineral resources of Jack Bay and vicinity Prince William Sound, in Mineral Resources of Alaska, 1917 : U. S. Geol. Survey Bull. 692, p. 171, 1919. 
mining stopped, but all the buildings and much of the machinery have been destroyed through natural decay and vandalism. At present, little remains at the beach to indicate that the place had been occupied except an old boiler, some tram buckets, sheave wheels, and iron castings. The principal building at the mine was burned with resultant destruction of the equipment housed there.

The predominant rock of the copper-bearing area is greenstone which is separated by the Landlocked Bay overthrust fault from the interbedded slate and graywacke on the east. The ore deposits are in the sheared and shattered zone bordering the fault and crop out on four claims known as the Vesuvius, Sunnyside, Copper Crown, and Sheep Run claims. Most of the development work was done in a branching tunnel 900 feet above the level of the bay, which was expected to cut the ore body of the Vesuvius claim at a depth of several hundred feet below the outcrop. When the property was visited by Johnson ${ }^{8}$ in 1912 , a tunnel 2,200 feet long had been driven on the Starvation claim, and several shorter tunnels had been driven higher on the mountain side at altitudes of $1,060,1,180$, and 1,400 feet to explore the Vesuvius ore body. Four hundred feet of adit, a shaft 47 feet deep, and open-cuts had been completed on the Sunnyside claim about 1 mile west of the camp at the Starvation claim tunnel and 800 feet above it. A shallow shaft and open-cuts had been opened on the Copper Crown lode, 1 mile to the south of the long tunnel and 1,350 feet higher.

The ore of all the claims consists of chalcopyrite, pyrrhotite, pyrite, and sphalerite, which replace the shattered country rock or fill fractures and larger cavities. The gangue minerals are quartz and calcite intermingled with fragments of the country rock. The ore bodies were formed in shear zones that range in thickness from a few inches to 20 feet. The prevailing trend of the shear zones is nearly east-west and the dip is high, in places south, in others north, but the recorded strikes range from $\mathbf{N}$. $65^{\circ} \mathrm{W}$. through east-west to N. $60^{\circ} \mathbf{E}$.

Notwithstanding the very considerable extent of the work done by the Galena Bay Mining Co., the mine was never brought to the productive stage, and seemingly no further development work was undertaken after the claims were patented.

\section{BOULDER BAY}

In the early days of mining on Prince William Sound, prospecting for copper was carried on near the head and on the east side of Boulder Bay by the Reynolds-Alaska Development Co. ${ }^{9}$

\footnotetext{
${ }^{8}$ Capps, S. R., and Johnson, B. L., The Ellamar district, Alaska : U. S. Geol. Survey Bull. 605, p. $99,1915$.

${ }^{\theta}$ Grant, U. S., and Higgins, D. F., Reconnaissance of the geology and mineral resources of Prince William Sound, Alaska: U. S. Geol. Survey Bull. 443, p. 61, 1910.
} 
The principal evidence of the work is a tunnel that was driven eastward into the mountain a few feet above the high-tide level and that includes a complicated system of crosscuts, winzes, and raises in interbedded greenstones, slates, and graywackes. The length of the openings is about 2,000 feet. One hundred and fifty feet above the long tunnel is a second opening, 200 feet long. The equipment included a wharf, steam power plant, generator, air compressor, office and bunkhouse, supply house, houses for the superintendent and the mining engineer, and the necessary mine equipment and machinery. Almost none of this equipment remains today, and practically all surface evidence of the operations has been destroyed by the waves or is concealed by the new growth of vegetation. Some of the equipment was sold for use in other mining undertakings on Knight Island; the rest was abandoned and has disappeared. At least two shipments of ore in an unknown amount are reported to have been made from the property, but no mining was done after 1909 .

The ore was typical of the district and consisted of chalcopyrite associated with other sulfides among which pyrrhotite was dominant. Part of the ore-shipped was from two large boulders found on the beach near the mine and another part was from an open-cut near the main tunnel.

\section{ELLAMAR}

The Ellamar mine is on Virgin Bay on the east side of Tatitlek Narrows about 20 miles southwest of Valdez (pl. 4). Although idle at present, it was formerly one of the two largest producers of copper in the Prince William Sound district. The early history and operations of the Ellamar mine were described by Capps and Johnson ${ }^{10}$ at the time when mining was most active.

The ore body, which cropped out on the beach between high and low tide, was discovered by M. O. Gladhaugh and C. Peterson in 1897. The first shipment of ore from the outcrop was reported to have been made in 1900. A shaft was started in 1901 and the Ellamar Mining Co. was formed in 1902. From 1900 to 1919, development work and production of copper ore were continued with little interruption. During 1909 and 1910 a cofferdam was built around the outcrop to keep out the sea water and enable mining to be done between the surface and the 100-foot level. By 1913 the shaft had been sunk to the 600 -foot level, or 70 feet below the bottom of the known ore body. Production, chiefly from the levels above the 400, continued until the smelter demands for the type of ore mined at Ellamar were met from other sources. When mining was stopped the mine was fully equipped

\footnotetext{
${ }^{10}$ Capps. S. R. and Johnson, B. L. The Ellamar district, Alaska : U. S. Geol. Survey Bull. 605, pp. 87-92, 1915.
} 
with power plant, machinery, buildings, ore bunkers, and a loading tram for conveying ore from the bunkers to ships. Since 1919 the mining machinery has been removed, the tramway has been torn down, and the buildings have been converted for use as a salmon cannery.

The Ellamar mine is within the area mapped by Capps and Johnson as lower slates and graywackes of the Orca group. The rocks exposed within the cofferdam are black slate, black limestone, dark argillites, and a few beds of fine-grained graywacke; they strike northwest and dip $80^{\circ} \mathrm{NE}$. They were badly crushed and sheared before the ore body was formed and are cut by at least one major fault, which strikes N. $60^{\circ} \mathrm{W}$. and dips $55^{\circ} \mathrm{NE}$. and is exposed in the lower part of the mine.

The ore body is a large lenticular mass of sulfides that strikes N. $35^{\circ}$ W. and dips $80^{\circ} \mathrm{NE}$. The lens pitches steeply to the southeast. Its maximum horizontal section is on the 200 -foot level where the greatest diameter is 240 feet and the least is 90 feet. It is made up of two parts, an overlying lens-shaped mass of solid pyrite and an underlying mass consisting of parallel lenses of other sulfides. The two are separated by a thin bed of slate. The pyrite has a maximum thickness of 35 feet and extends from the surface to the 300 -foot level. The other sulfide bodies that furnished most of the ore are irregularly distributed.

The minerals in the ore include chalcopyrite, chalmersite, pyrrhotite, pyrite, and sphalerite. Galena is probably present, for the smelter returns show lead. The ore also contains a small quantity of gold. Quartz, brownish-black calcite, white calcite, and country rock comprise the gangue material.

The ore mined in the later years of operation was of such low grade that its extraction was no. longer profitable under the conditions existing when mining ceased. This situation rather than exhaustion of the low-grade ore is reportedly the reason for closing the mine.

\section{LANDLOCKED BAY}

Landlocked Bay, north of Port Fidalgo (pl. 4), is in an area of greenstone and associated sedimentary rocks that offered favorable conditions for sulfide mineralization in many places. The deposits are of one general type, replacements of crushed rock and fillings of cavities along shear zones in greenstone by iron and copper sulfides. The greenstone is commonly associated with a little graywacke and black slate, and the shear zones probably resulted from the disturbances associated with the development of the Landlocked Bay overthrust fault which extends southeastward from the head of Jack Bay at least to Port Fidalgo. 
The copper properties of Landlocked Bay may be divided into two groups: Those that shipped a significant quantity of ore to the smelter and those that either shipped none at all or shipped so little that they can be considered no more than promising prospects. In the first group are the claims of the Threeman Mining Co., the Landlocked Bay Copper Mining Co., and the Standard Copper Mines Co.

\section{THREEMAN MINING CO. CLAIMS}

The principal property of the Threeman Mining Co. is at the head of Landlocked Bay (pl. 4). A majority of the claims, including the Keystone from which most of the ore shipped to the smelter was taken, are on the north side of the bay. The Keystone claim, which was staked about $1903,{ }^{11}$ produced a small shipment of 12 percent ore in 1904. Other shipments were made in 1906; and regular shipments began in 1912. The last shipment was in 1915, although ore was broken in the stopes the following year.

The equipment included several buildings, a short tram, ore bunker, and sorting house, and a long pier to accommodate steamers loading ore. All these structures are now in ruins.

More than 5,000 feet of adits, drifts, and crosscuts were driven, and the ore was explored from five different levels at altitudes of 282,235 , 122 , and 57 feet. Between 5,000 and 6,000 tons of 8 percent ore was shipped to the smelter.

The country rock includes greenstone, graywacke and slates, which are separated from the nearby older slates and graywackes on the east by the Landlocked Bay overthrust fault. As the rocks are much faulted and shattered, they offered favorable channels for the orebearing solutions.

The shipping ore was derived in large part from two lenticular ore bodies made up of nearly solid sulfides. The ore bodies differ slightly in strike but considerably in dip; thus, although only 20 feet apart on the level of adit 2 they diverge downward and are farther apart on the level of adit 5. The more northerly body with smaller dip was exposed by the two highest levels, the underlying body by the three lower levels.

\section{LANDLOCKED BAY COPPER MINING CO. CLAIMS}

The Landlocked Bay Copper Mining Co. (Dolan and Rystrom) owned claims on the soutin side of upper Landlocked Bay half a mile southwest of the Threeman Mining Co.'s property. The copper deposit was discovered in 1898 but was not immediately exploited;

\footnotetext{
${ }^{11}$ Capps, S. R. and Johnson, B. L., The Ellamar district, Alaska : U. S. Geol. Survey Bull. 605 ; p. 92,1915 .
} 
only a little development work was done on it until after the company ${ }^{12}$ was incorporated in 1906. Although the property included several claims covering mineralized ground, most of the mining was done on three claims. The equipment of the mine included a $\log$ bunker with a capacity of 800 tons, a trestle way about 150 feet long connecting the bunker with the mine entrance, and quarters for living. This installation is now in ruins.

The principal adit was started near the beach and 80 feet above it and was driven southward to expose the ore. This adit cut an ore body in a shear zone in slate and a little limestone. The adit followed the zone in a curving course which changed from S. $76^{\circ} \mathrm{E}$. at the place where it first struck the ore to south at the end of the drift. The dip varied also and changed from steep north to low east. Two ore shoots were found in which the ore body ranged from 1 to 7 feet in thickness and had a stope length of 25 to 30 feet.

The sulfide minerals present were chalcopyrite, pyrrhotite, sphalerite, and a few specks of chalmersite, which replaced the crushed matter of the shear zone and to a lesser extent filled fractures in the shattered black slate. A little ore, reported to contain $71 / 2$ percent of copper, was shipped from these stopes.

\section{STANDARD COPPER MINES CO. PROPERTY}

The property of the Standard Copper Mines Co., which in early days was locally known as the Burke and Steele property, is on the south slope of Copper Mountain at the entrance to the upper narrow part of Landlocked Bay. The ore deposits are high up on the steep mountain slope and were discovered early in the history of copper mining in this district. The company ${ }^{13}$ was not formed until 1906, and niost of the development work took place after that date although nothing appears to have been done in recent years. When Grant visited the property in 1908 the mine was connected with an ore bunker at the beach by a wire-rope aerial tramway consisting of two sections, a lower part, 2,526 feet long and an upper part 923 feet long, which led to the mouth of a tunnel 2,000 feet above sea level. In addition to the bunker of 500 tons capacity the mine was equipped with a short pier, several substantial buildings at the beach, and other buildings at the upper end of the tram. Only the dismantled bunker and one of the upper buildings were standing in 1943.

\footnotetext{
12 Capps, S. R. and Johnson, B. L., The Ellamar district, Alaska : U. S. Geol. Survey Bull. 605, p. 96,1915 .

${ }^{13}$ Grant, U. S., and Higgins, D. F., Reconnaissance of the geology and mineral resurces of Prince William Sound. Alaska: U. S. Geol. Survey Bull. 443, p. 62, 1910. Capps, S. R. and Johnson, B. L., The Ellamar district, Alaska: U. S. Geol.-Surves Bull. 605, pn. 104-106, 1915.
} 
In 1915, Capps and Johnson reported that the underground workings had a length of about 1,300 feet and include five tunnels and a 50 -foot winze. The ore bodies were lenticular masses of sulfides and bunches of sulfides at the intersections of shear zones in greenstone interbedded with a little graywacke and black slate. All the ore was in greenstone. Several hundred tons of high-grade ore were shipped between 1906 and 1911.

\section{OTHER DEPOSITS ON LANDLOCKED BAY}

Among the other mining properties on Landlocked Bay (pl. 4) are several on which exploratory work was done, but which did not produce significant quantities of shipping ore. Some of these claims are patented, but apparently no work has been done on any of them in recent years; their equipment has been removed, and the buildings for the most part are now in ruin or are unusable.

The Reynolds-Alaska Development Co. prospected claims about 1 mile north of Landlocked Bay. Approximately 900 feet of underground development work had been done in 1915. This included two adits of 600 feet and 220 feet, respectively, and several short adits, open-cuts and a shallow shaft.

The property of the Hemple Copper Co. is north of the ground of the Threeman Mining Co. and consists of six patented claims and a mill site. The underground development work in 1915 amounted to about 1,350 feet, comprising four adits $800,450,65$, and 18 feet long, respectively, and two shafts, 10 and 15 feet deep. The copper deposit was reported to be a mineralized shear zone of irregular width averaging 24 feet, cutting greenstone, black blocky slate, and graywacke.

In addition to its operations on the Keystone claim the Threeman Mining Co. prospected the ground originally owned by the Alaska Commercial Co. and the Montezuma claim, both of which lie between the Threeman mine and the workings of the Standard Copper Mines Co. The workings on the Alaska Commercial Co. ground included (1915) three tunnels with a total length said to be more than 532 feet. Several tons of high-grade ore (reportedly) have been shipped from the upper adit, 450 feet above the nearby beach.

The deposit of the Montezuma claim crops out at an altitude of 1,400 feet above the beach; it is a little lower than the workings of the Standard Copper Mines Co. and east of them. It was explored by underground drifts and crosscuts totaling about 370 feet in length and by about 900 feet of surface stripping. The country rock is dominantly greenstone; the ore body occurs in a mineralized shear zone where it was formed by the impregnation and replacement of sheared greenstone by chalcopyrite and pyrite. 


\section{PORT FIDALGO}

Port Fidalgo extends from east to west across the mineralized area that centers in Copper Mountain and includes Ellamar and Landlocked Bay. The geology of the surrounding country has not been worked out in detail, but so far as known the rocks south of Port Fidalgo are like those on the north and comprise chiefly slate, graywacke, and associated greenstones. The great Landlocked Bay overthrust fault, if projected southeastward in the direction of its general trend would pass through or near the depression occupied by Irish Cove. Probably this fault or subsidiary faults of the zone was a factor in determining the location of the copper deposits, as it furnished structural conditions favorable for the circulation of ore solutions and for the deposition of copper and iron sulfides.

Mining or prospecting was carried on in three principal places on the south side of Port Fidalgo: On the north front of the mountain east of Irish Cove, on the south front of the same mountain, and on the mountain slope 5 miles east of Irish Cove. These localities were visited by Johnson ${ }^{14}$ in 1913, by the senior author in 1923, and by both authors in 1943 .

\section{FIDALGO-ALASKA COPPER CO: CLAIMS}

The copper deposits east of the entrance to Irish Cove were mined by the Fidalgo-Alaska Copper Co. (pl. 4). The claims, commonly known as the "Schlosser property" from the name of their discoverer, have had a longer history of production than most of the other copper mines on Prince William Sound, except those at Latouche and Ellamar.

The Fidalgo-Alaska Copper Co. was formed in 1907 and began development work that year. Small shipments of ore to the smelter were made at irregular intervals prior to 1916, but from 1916 to 1920, shipments were regular. The total quantity of ore shipped to the smelter prior to 1920 was reported to be approximately 16,000 tons, which averaged about 10 percent of copper. The mine has been idle since 1920. Changes in ownership have taken place and the property now is in the control of the Alaska Copper Corp.

The mine was equipped with the necessary buildings for handling the ore and taking care of the personnel, and with a wharf for loading. Ore was brought from the mine to the bunker at the beach by a wire tram approximately 2,700 feet long. All the buildings, the wharf, and the tram are now in ruins and must be replaced if the mine is reopened.

\footnotetext{
${ }^{14}$ Capps, S. R. and Johnson, B. L., The Ellamar district, Alaska : U. S. Geol. Survey Bull. 605, pp. 112-122, 1915 .
} 
The ore bodies that were mined are nearly half a mile from the beach and range in altitude from about 680 feet to 990 feet. Five principal adits were driven at altitudes of $200,680,810,920$, and 990 feet: These measurements were made with the barometer and are subject to correction. Ore was mined from the four upper openings. The lowest tunnel was driven from a point nearly 1,900 feet from the upper workings south to tap the ore body at depth but had failed to reach it when the low price of copper put an end to mining. Geophysical prospecting reportedly indicated the presence of mineralized ground that has not yet been proved by excavation or drilling.

\section{FIDALGo MINING Co. PROPERTy}

The property of the Fidalgo Mining Co., locally known as the Blakney property, is on the south side of Port Fidalgo about 1 mile west of Whalen bay (pl. 4). It formerly included 24 claims, but development work was done on only two claims, the Winchester and Elgin, about half a mile from the beach and nearly a thousand feet above it. Two tunnels were driven at altitudes of approximately 850 and 950 feet. Most of the work on the longer and lower tunnel was done in 1907. Johnson ${ }^{15}$ states that little was done after that until the fall of 1912 and the winter of 1912-13. In 1913 the development work consisted of a tunnel 240 feet long at an altitude of about 850 feet and a second tunnel 240 feet long at 950 feet. These were connected by a raise that was extended to the surface. From the mouth of the lower tunnel a track 900 feet long, for tramcars, led to a sorting house and the loading station of an aerial wire tramway over which the ore was carried to the bunker at the beach. This wire tramline was 2,000 feet long, carried two buckets, and had a capacity of 40 to 50 tons a day. Later, a lower tunnel, about 400 feet below the tramcar level, was driven 300 feet along the shear zone, and a raise was put up to the main tunnel. This new tunnel was intended to be the main working level and 2 two-story buildings were built nearby for living quarters and cook house. The equipment at the beach included a $\log$ ore bunker, a wharf, and a cabin on a small stream one-third mile east of the bunker. This stream provided a route for the trail to the mine and furnished water to drive a small power plant. As all the buildings and the equipment are either in bad repair or completely ruined, they must be replaced if mining is resumed.

The ore consists of chalcopyrite, pyrite, and pyrrhotite in a shear zone in greenstone and associated sedimentary beds. The strike of the shear zone ranges from N. $4^{\circ}$ E. to N. $6^{\circ} \mathrm{W}$. and its $\operatorname{dip}$ from $55^{\circ}$ to $75^{\circ} \mathrm{E}$. Two main ore bodies in the shear zone were mined. On the

\footnotetext{
${ }^{15}$ Canns. 'S? R.: and Johnson,.B. L., The Ellamar district, Alaska : U. S. Geol. Survey Bull. 605. p. 114. 1915 .
} 
upper level the ore-bearing zones are from 5 to 7 feet apart; on the lower level they are only 2 to 3 feet apart. The lower ore body had a maximum thickness of 3 feet and was of somewhat lower grade than the upper body, which had a maximum thickness of $41 / 2$ feet. and contained 14 percent of copper:

Two stopes on pitching shoots about 40 feet apart were mined on the main or tram level. Smaller bodies reported to be of somewhat lower grade were mined in the upper tunnel and crop out at the surface 100 feet above that tunnel. Shipments of cre were made from stopes between the two levels and from the upper level. Most of the mining.was done in 1913.

\section{DICKEY COPPER CO. CLAIMS}

The claims of the Dickey Copper Co., originally known as the Mason and Gleason claims, are east of Irish Cove and not more than half a mile south or southeast of the Fidalgo-Alaska Copper Co.'s mine, but on the south side of the mountain (pl. 4). Most of the development work on these claims was done between 1910, when $\mathrm{Mr}$. W. A. Dickey first bonded the claims, and 1913 when they were visited by Johnson. ${ }^{16}$

The development work included two principal adits at altitudes of 470 and 540 feet. Between the two is a shorter intermediate adit and 30 feet above the upper adit is a short crosscut tunnel on the ore body. An inclined raise connects the intermediate adit with the upper adit. A stope from which ore was extracted extended from the upper adit to the surface. Approximately 660 feet of crosscuts and drifts were driven, and raises were put up from both main tunnels. About 600 tons of ore was mined in 1913, but no shipments were made at that time.

The mine equipment included cabins for living quarters and ore bunkers at both the mine and the shore of Irish Cove, together with several minor buildings, such as blacksmith shop and storeroom.

The ore consists of chalcopyrite, pyrite, sphalerite, and pyrrhotite deposited in shear zones in sedimentary rocks that include thinbedded graywacke, argillite, and slate. No greenstone is found at the mine or in its immediate vicinity. In addition to copper some of the ore carries a considerable quantity of gold.

\section{ORCA BAY}

One of the smaller areas of greenstone of the Prince William Sound district is east of Orca Bay and includes the vicinity of Cordova and the mountains to the northeast. This area, like the greenstone areas in

\footnotetext{
${ }^{16}$ Capps, S. R. and Johnson, B. L., The Ellamar district, Alaska : U. S. Geol, Surver Bull. 605 , p. $120,1915$.
} 
general, is a place where copper minerals are present; therefore it attracted the attention of copper miners. A number of prospects showing copper minerals were found in both the greenstone and the slate and graywacke beds that surround them. Exploratory work was undertaken on some of these prospects, but it failed to reveal deposits of commercial importance and was accordingly discontinued. So far as known to the writers, development work has not been done on any of these claims in recent years.

\section{SOUTHWESTERN PRINCE WILLTAM SOUND}

The copper mines and prospects of the southwestern part of Prince William Sound are situated for the most part on Latouche and Knight Islands. (See pl. 5.) The early discovery of the Beatson-Bonanza ore body at Latouche attracted attention to this area and brought many prospectors to it, who extended the search to nearby Knight Island. , Notwithstanding the presence of copper minerals in several places on Latouche Island, only one productive' mine has been developed there. This mine comprised the several ore bodies at Latouche that at one time were an important source of Alaskan copper. Knight Island has furnished no important producing mine but has many promising prospects, among them the copper deposits at Rua Cove, ${ }^{17}$ which are of considerable volume although of. low grade and of marginal value.

\section{LATOUCHE ISLAND}

\section{LATOUCHE 18}

The Beatson mine at Latouche is on the west coast and near the north end of Latouche Island. It is owned by the Kennecott Copper Corp. and, operating as the Beatson Copper Co., was once the most productive of the copper mines of Prince. William Sound. Next to the mines at Kennecott, it was the largest producer of copper in Alaska.

The original discovery of copper on Latouche Island was made in 1897. The Beatson-Bonanza, as it was formerly called, was the first prospect staked. The first small trial shipment of ore from the Beatson-Bonanza was made in 1899 and was followed at irregular intervals by other trial shipments that totaled 100 tons in 1903 . In

\footnotetext{
${ }^{17}$ Stefansson, Karl and Moxham, R. M., Copper Bullion Claims, Rua Cove, Knight Island, Alaska : U. S. Geol. Survey Bull. 947-E, 1946.

${ }^{18}$ The following publications contain descriptions of the copper deposits at Latouche: Lincoln, F. C., The Big Bonanza copper mine, Latouche Island, Alaska: Econ. Geology, vol. 4, pp. 201-213, 1909. Grant, U. S. and Higgins, D. F., Reconnaissance of the geology and mineral resources of Prince William Sound, Alaska: U. S. Geol. Survey Bull. 443, pp. 63-66, 1910. Johnson, B. L., Copper deposits of the Latouche and Knight Island districts, Prince William Sound, in Mineral Resources of Alaska, 1916: U. S. Geol. Survey Bull. 662, pp. 204-206, 1918. Bateman, Alan M., Geology of the Beatson copper mine, Alaska: Econ. Geology, vol. 19, pp. 338-368, 1924.
} 
1904 the mine became a regular shipper. In 1910 the Kennecott Copper Corp. took control, consolidated the Beatson with other claims, and operated the mine till 1930 when the ore of commercial grade was exhausted.

The property as it was finally made up included three principal ore bodies on which a number of claims were staked. The first is the Beatson ore body, much the largest and most productive of the three. Nearly 1,000 feet north of the Beatson is the Chenega, the smallest and least productive. Slightly more than 1,000 feet farther north is the Ladysmith, also known by the names Blackbird, Girdwood, and Barrack. The Beatson and Ladysmith ore bodies were originally independent properties. In the beginning they were developed separately and passed through various ownerships before they were finally acquired by the Kennecott Copper Corp. On taking control the Kennecott management immediately stepped up the production to such a rate that additional facilities were required for mining, milling, and shipping ore. The added personnel was considerable. The employees and their families were enough to form a small town which became a regular port of call for steamships, although its activities were all dependent on the mine. After mining was ended most of the machinery was dismantled and sold. When visited by the authors in 1943, a watchman was looking after the property and was maintaining the two pipelines that furnish water and provide power and light for his use and that of a few persons who were occupying some of the cottages.

The Bonanza ore body was mined by a large open-cut and several irregularly spaced, underground levels, the lowest of which is 150 feet below sea level. The Chenega ore body was explored by two levels and the Ladysmith by six, besides numerous open-cuts and several shafts. A drift was projected northward from the 200-foot level of the Bonanza mine to tap the Chenega and Ladysmith ore bodies. This drift was carried to a point below the Chenega ore body, but whether it was extended as far as the Ladysmith is not known to the writers.

The rocks in the vicinity of Latouche consist chiefly of graywacke and slate but include a few beds of conglomerate and limestone. They are folded, faulted, and intruded in a few places by igneous rocks. A lamprophyre dike occurs underground in the Beatson mine. ${ }^{19}$ Another uncommon rock type in the Beatson mine is a hard flinty rock, important as a copper bearer, that probably is an altered sedimentary bed.

\footnotetext{
${ }^{10}$ Bateman, Alan M., Geology of the Beatson copper mine, Alaska: Econ. Geology,
} vol. 19 , p. 346, 1924 . 
The ore bodies at Latouche and those near Horseshoe Bay, 2 miles south of the Beatson mine, are in a fault zone that extends almost the full length of Latouche Island and that caused an unknown but possibly large displacement of the beds affected. The fault zone dips steeply to the west and is made up of many subsidiary faults of local importance and variable extent. 'The ore consists chiefly of chalcopyrite, pyrrhotite, and pyrite but includes other sulfides such as sphalerite, chalmersite, and galena. Small quantities of gold and silver and a little native copper are present in weathered outcrops.

As described by Bateman, ${ }^{20}$ who has given the most comprehensive account, the ore body of the Beatson mine is on the east or footwall side of the Beatson fault, one of the major faults in the fault zone. Adjacent to the fault in general is a mass of pyrite and pyrrhotite that ranges from 2 to 40 feet in thickness; it was traced horizontally for about 800 feet. Adjacent to the fault in places were small lodes of ore, containing from 5 to 10 percent of copper, that were mined and shipped direct to the smelter. The principal ore body consisted of chalcopyrite, pyrrhotite, and pyrite in grains scattered through the altered country rock and in small veinlets associated with quartz. The shape and size of an ore body that could be mined with profit was determined by economic factors rather than by definite, natural boundary surfaces. Bateman described the metallized ground as a huge fat lens, flat on the west side and with protuberances on the other. This lens had a horizontal length of about 1,000 feet and a width of 400 feet. 'The method of mining by caving proved highly efficient and made profitable the extraction of ore containing less than $11 / 2$ percent of copper. Some of the high-grade ore was shipped without mill treatment, but most of the output of the mine was concentrated before being sent to the Tacoma smelter.

The Ladysmith and Chenega ore bodies are similar in general character to the Beatson. The rocks are slate and graywacke. The ore bodies show the same sulfides and are deposited in a strong fault zone, which is the same as that at the Beatson. Faulting and shearing, quite noticeable in the Ladysmith, made necessary an unusual amount of timbering in the tunnels. This mine had already produced highgrade shipping ore before it was acquired by the Kennecott management.

\section{HORSESHOE BAY}

The copper deposits near Horseshoe Bay are about 2 miles southsouthwest of the Beatson mine and are less than 1 mile from the beach. They were owned and explored by the Reynolds-Alaska Development

${ }^{20}$ Bateman, Alan M., op. cit. p. 349 . 
Co. ${ }^{21}$ These deposits are said to have been located in 1898. Development work on them was started shortly after and continued till 1916, but it has not been carried on in recent years.

Most of the work was done on two claims known as the Duke and Duchess. The principal buildings and a water-power plant for generating electric current were located on Horseshoe Bay, from which a corduroy road a little more than three-fourths of a mile long was built to the two claims.

The buildings and equipment on the property at Horseshoe Bay were not maintained and are now unusable; the rails, cars, and oId tools that were left at the mine workings are worthless.

The country rock of the vicinity is mainly interbedded graywacke and black slate with some light-gray slate, chert, and limestone. These beds are folded and faulted. 'The sulfide bodies that make up most of the deposit are in a major fault zone that is almost parallel to the strike of the country rock and is the same fault zone as that in which the ore bodies at Latouche occur.

The principal opening of the Duke claim is a 110 -foot shaft half a mile from the beach and 150 feet above it. From the shaft a crosscut was driven 100 feet eastward to the ore body; from that point drifts were driven both north and south on the ore. The surface outcrop of the Duke claim shows a mineralized belt from 200 to 250 feet wide. The shaft revealed a single ore body that includes a westwarddipping lens of sulfides-chalcopyrite, pyrite, and pyrrhotite-with a maximum thickness of 27 feet and a developed length of 140 feet.

Exploration of the Duchess ore body was carried on from two adits at altitudes of 400 and 500 feet, respectively, and from a third short adit higher on the hill at 630 feet above sea level. The tunnels of the Duchess claim reveal a mass of solid sulfides, mainly pyrite and pyrrhotite, of unknown depth, having a proved length of 500 feet and a width ranging from 6 inches to 122 feet but averaging between 25 and 30 feet. The best source of copper, however, was the chalcopyrite disseminated in graywacke, rather than the massive sulfide mass. Shipments of ore were made from both the Duke and the Duchess claims.

\section{OTHER DEPOSITS ON LATOUCHE ISLAND}

Copper minerals were found at other places on Latouche Island but not in quantities sufficient for profitable mining, although considerable exploratory work was done on some of the prospects. Among such prospects are those at Wilson Bay about halfway between Latouche and Horseshoe Bay on the west side of the island and those

\footnotetext{
${ }^{21}$ Johnson, B. L., Copper deposits of the Latouche and Knight Island districts, Prince William Sound, in Mineral Resources of Alaska, 1916: U. S. Geol. Survèy Bull. 662, pp. 206-208, 1918.
} 
near Montgomery Bay near the south end of the island. At Montgomery Bay the Seattle-Alaska Copper Co. drove two adits at altitudes of 1,150 feet and 1,450 feet, respectively, above sea level. The tunnels are in a shear zone in graywacke and slate and are near, if not on, the fault zone that includes the ore bodies at Latouche and Horseshoe Bay. No development work has been done on these claims for many years.

\section{KNIGHT ISLAND}

Copper minerals occur at many places on Knight Island. Greenstone, commonly in the form of pillow lavas, makes up most of the country rock but is interbedded with or intruded into inconspicuous shale and graywacke beds, which locally are the prevailing rocks. The largest area of the dominantly sedimentary beds is at the south end of the island, where these rocks are exposed along the shore from Snug Harbor to Point Helen. The lava flows and interbedded shale are folded and much faulted. Faults and shear zones provided channels for the circulation of copper-bearing solutions and made conditions favorable for the deposition of the sulfides that make up the ore deposits. Although the copper and associated sulfide minerals are not restricted to areas of greenstone, by far the larger porportions of the deposits are in it. Areally, more copper deposits are known in the southern part of the island than in the northern part. Grant and Higgins ${ }^{22}$ listed 41 prospects which were controlled by about 30 different owners in 1909, and stated that the list did not include all the prospects that had been found. Johnson ${ }^{23}$ described 16 localities where copper deposits were either being prospected or had had exploratory work done on them in 1916. Since that time nearly all the claims that cover these deposits have been abandoned. However, a few were patented and therefore required no further annual assessment work; a few have had assessment work done on them except when it was remitted by law. Several prospects on Knight Island made small trial shipments of ore to the smelter, but none of them ever reached the status of sustained production.

The ore deposits of Knight Island are of the same general type as those found elsewhere on Prince William Sound. Johnson ${ }^{24} \mathrm{de}-$ scribes them as follows in a statement that was intended to apply to Latouche Island as well as to Knight Island:

The mineralogy of most of the ores is simple; the minerals are few and are common to most of the properties. Certain of the Knight Island prospects,

\footnotetext{
2 Grant, U. S., and Higgins, D. F., Reconnaissance of the geology and mineral resources of Prince William Sound, Alaska : U. S. Geol. Surrey Bull, 443, p. 10, 1910.

${ }^{23}$ Johnson, B. L., Copper deposits of the Latouche and Knight Island districts, Prince William Sound, in Mineral Resources of Alaska, 1916: U. S. Geol. Survey Bull. 662, p. 194, 1918.

24 Johnson, B. L., op. cit., p. 203.
} 
however, contain chalmersite, a rare copper-iron sulfide not observed in most of the copper-bearing ores of the two districts.

The economically important copper-bearing minerals are chalcopyrite and chalmersite, which occur intimately associated at some of the Knight Island prospects. Gold or silver, or both, occur in some of the ores. The gold is probably native. The combination in which the silver occurs is not known.

The original metallic minerals of these ores are chalcopyrite, chalmersite, pyrrhotite, pyrite, sphalerite, galena, gold, and silver. Traces of arsenic and nickel are reported in some of the ores. The non-metallic minerals include quartz, feldspar (?), chlorite, a brown-weathering cream-colored carbonate, calcite, and epidote.

Minerals resulting from the weathering of the original ore minerals are native copper, chalcocite, covellite, melaconite, malachite, azurite, and the yellow and red oxides of iron. These secondary minerals are of no economic importance because of their scarcity, the ore bodies having been but slightly oxidized since the comparatively recent glaciation of these districts.

The descriptions of mining claims that follow are intentionally no more than brief statements of the exploratory work that has been dọne on the most promising of the copper prospects and of the mineralization and general geologic relations shown by them. The numerous changes in ownership and the common practice of designating a mining project in various ways, as by its discoverer's name, a claim name, a locality name, or a company name, tends to confuse the identity of some properties. The present ownership of many properties is unknown to the writer and is difficult to determine, for although most of the unpatented claims were abandoned completely, some were held for a while or were transferred, and some were restaked. The statements regarding the extent of the development work do not give the full picture of what was accomplished on some claims, for additional work was done on them after they were visited by representatives of the Geological Survey. A record of this work may never be obtained, for many underground openings are now either partly or completely inaccessible because of caving or flooding. The underground openings on some prospects, however, are now just as they were when visited by Johnson in 1917.

For convenience in comparison, the reference to mining prospects on Knight Island will be given by localities and in the same order as was used by Johnson ${ }^{25}$ except for the description of Rua Cove, which has been published separately.

LOUIS BAY

A company known as the Knights Island Mining and Development Co. prospected showings of copper $1 \frac{11}{2}$ miles south of the head of Louis Bay at the north end of Knight Island. The principal development work comprised two tunnels at the south end of the valley at the

${ }^{25}$ Johnson, B. L., op. cit., pp. 211-220. 
head of Louis Bay at altitudes of approximately 550 feet and 900 feet. At present the lower tunnel, which apparently was driven to tap the ore exposed at the upper tunnel, is inaccessible. According to Johnson ${ }^{26}$ the upper tunnel was 75 feet long and led to a short drift and winze on the ore body.

The bedrock in this part of Knight Island is chiefly greenstone, which commonly displays well-developed pillow structure, interbedded with a little slate. The greenstone at the mining property is sheared and somewhat mineralized. The chief constituents of the mineralized bodies are pyrrhotite and chalcopyrite, which are associated with sphalerite, pyrite, quartz, epidote, and chlorite.

The equipment for mining included facilities for housing miners at the mine and the beach, small hydroelectric plants, and a small sawmill at the beach, only the ruins of which remain. The road from the beach to the camp is overgrown with brush and small trees.

Several open-cuts and short tunnels in the upper valley and two short tunnels near the beach indicate further prospecting in this vicinity. Some of this work may have been done by other prospectors.

\section{HERRING BAY}

The Crown Copper Co. once did exploratory work, represented by a . short tunnel and several open-cuts, at the head of the most easterly arm of Herring Bay. The tunnel is about one-fourth mile from the beach, at an altitude of 110 feet. It was driven in slightly shattered greenstone which, in this part of Knight Island, shows pillow structure developed in unusual perfection. The tunnel is 30 feet long and has a short drift on the north or northeast side. Several open-cuts were made near the tunnel. No ore is exposed in the tunnel but specimens from the dump contain quartz, pyrite, pyrrhotite (?), sphalerite, and chalcopyrite.

\section{BAY OF ISLES}

Several claims were staked on the Bay of Isles, but only one group will be considered-the Pandora group, about half a mile west of the head of the south branch of the bay across the divide from Marsha Bay. This property originally belonged to Messrs. Wallace, McPherson, and Valentine and was discovered early in the exploration of Knight Island.

The principal body of mineralized rock is about 400 feet above sea level and crops out in a narrow rock-walled box canyon 25 to 30 feet deep. It was explored by a shaft 95 to 100 feet deep which was sunk on the west side of the canyon, and by a branching adit driven into the west wall of the canyon a little above the creek. This adit and

${ }^{26}$ Johnson, B. L., op. cit., pp. 211-212. 
its branch include more than 150 feet of tunnel work. Drifts and crosscuts were driven from near the bottom of the shaft and from a level about 65 feet below the surface. A few heavy timbers and some irons are all that remain of the head frame and of the buildings near the shaft.

The bedrock is greenstone, possibly including some graywacke, which was sheared and faulted and now appears in the surface outcrop as alternating bands of sheared and hard, unsheared rock. This sheared zone is possibly 100 feet wide, strikes N. $10^{\circ}$ to $15^{\circ} \mathrm{W}$. and $\operatorname{dips} 65^{\circ}$ to $80^{\circ} \mathrm{E}$. It is mineralized with copper and iron sulfides. The shaft is said to have been sunk on a 5 -foot lens of good ore. ${ }^{27}$

The valuable ore minerals are chalcopyrite and chalmersite associated with quartz, epidote, chlorite, pyrrhotite, sphalerite, and pyrite.

South-southwest of the shaft and 800 feet higher is an open-cut exposing a shear zone 12 feet wide, mineralized with quartz veins and sulfides of iron and copper.

\section{DRIER BAY}

Grant and Higgins ${ }^{28}$ visited Drier Bay in 1908. Their published report gives the locations of 10 copper prospects on the index map of Drier Bay and describes two prospects where work was in progress. Johnson ${ }^{29}$ visited this area again in 1916 and found that development work had been or was being done on 6 properties. No work was in progress on any of these properties during visits by the writers in 1924 and 1943. The following descriptions therefore are chiefly brief summaries of observations by Grant and Higgins and Johnson and some later observations by the writers.

\section{JONESY GROUP}

The Jonesy group of claims includes part of the property formerly controlled by the Knight Island Consolidated Copper Co., or HubbardElliott Co. as it was more commonly called. The principal activities of this company were on the Bald Eagle claim about half a mile east of the northernmost point in Drier Bay and about 1,000 feet above sea level. An aerial wire tram connected the mine with the ore bunkers at the beach where a small steam power plant and several buildings were located. Part of this installation was removed when the property

\footnotetext{
${ }^{27}$ Johnson, B. L., Copper deposits of the Latouche and Knight Island districts, Prince William Sound, in Mineral Resources of Alaska, 1916: U. S. Geol. Survey Bull. 662, p. 213,1918 .

${ }^{28}$ Grant, U. S. and Higgins, D. F., Reconnaissance of the geology and mineral resources of Prince William Sound, Alaska: U. S. Geol. Survey Bul. 443, pp. 10, 67-68, 1910.

${ }^{20}$ Johnson, B. L., op. cit., p. 194 and pp. 215-218.
} 
was abandoned and part has since been destroyed through natural decay. At present nothing usable remains of the mine equipment.

The country rock at the prospect is greenstone which is cut by a system of shear zones dividing the greenstone into bands of sheared and unsheared rock. The shear zones are mineralized. A tunnel showing about 350 feet of underground work at the time it was examined by Johnson was driven on a vertical shear striking N. $15^{\circ} \mathrm{W}$. About 75 feet east of the tunnel is another shear zone, which is cut in the tunnel and was the main source of the small quantity of the ore that was mined.

\section{MONARCH CLAIM}

The Monarch claim is another property that was part of the Hubbard-Elliott holding. This claim is described as being about $11 / 2$ miles northwest of the head of Drier Bay and 700 feet above sea level. The underground workings have a length of about 320 feet. The country rock is greenstone which is sheared and slightly mineralized in places. Pyrite and chalcopyrite, associated with epidote and quartz, were found on the dump but were not seen in the tunnel.

\section{NELLIE GROUP}

The Nellie group of claims is about one-third mile northeast of the head of Drier Bay or east of the northern arm of the bay. A mineralized shear zone crosses a deep gulch in the greenstone country rock at an altitude of 650 feet. It was explored by open-cuts, a 6-foot shaft and a 36-foot adit.

The shear zone strikes N. $25^{\circ}$ E. and dips $75^{\circ}$ E. On the north side of the gulch, in the face of the tunnel, the zone is 9 feet wide. The width increases to 20 feet on the south side of the gulch near the creek but it decreases upward and is only 15 inches at the last exposure, which is 250 feet higher than the creek. North of the creek the shear zone is poorly defined but apparently continues for at least threefourths of a mile. A 5-foot shaft was sunk in a 10-foot shear zone 550 feet above the tunnel: On the crest of the ridge, 750 feet above the tunnel or 1,400 feet above the bay, the shear zone strikes N. $25^{\circ} \mathrm{E}$. and ranges from 4 feet to 12 feet in width. The sulfide minerals are sparingly present in most of the shear zone and in the best showings form lenses as much as 2 inches thick. The ore minerals include chalcopyrite, chalmersite, pyrrhotite, and quartz.

\section{KNIGHTS ISLAND ALASKA COPPER CO. PROSPECT}

Exploration for copper deposits was carried on at several places. about the head of Drier Bay. The Knights Island Alaska Copper Co. prospected showings on Northeast Cove, a small, narrow inlet at the 
east end of Drier Bay. This prospect is northeast of the east end of Northeast Cove at an altitude of nearly 1,000 feet and is reached by a trail that leads through timber from the ruins of an old cabin on the north shore of the inlet into a narrow pass in the mountains, thence over the steep bare mountainside to the workings.

When visited by Johnson ${ }^{30}$ the underground excavation included more than 700 feet of crosscuts and drifts, a winze and a raise. The tunnel is in sheared greenstone and was projected to intersect an ore body that crops out on the mountains 200 feet above the tunnel. A shear zone was encountered in the tunnel, but it is only slightly mineralized.

On the surface at the outcrop the shear zone is poorly defined. It ranges from 20 to 50 feet in width, strikes N. $15^{\circ} \mathrm{E}$. and is traceable for a few hundred feet. The zone is not strongly mineralized but contains small lenses or bunches of solid or nearly solid sulfide minerals. Chalcopyrite, chalmersite, sphalerite, pyrrhotite, and quartz are the ore minerals. Johnson ${ }^{31}$ states that "basic dikes $* * *$ and irregular masses of basic igneous rocks cut and intrude the mineralized shear zone."

\section{COPPER COIN GROUP}

The Copper Coin group, which was described by Grant and Higgins ${ }^{32}$ under the title of Russell Ball Copper Co., was not being worked when visited by Johnson ${ }^{33}$ in 1916 and apparently has not been active since that time. The buildings at the beach and the wire tram to the beach and the wire tram to the workings on the mountain above have all disappeared.

This property is on the southeast side of Drier Bay between Barnes Cove and Mallard Bay. It consisted originally of four claims on Drier Bay and two claims over the ridge toward Snug Harbor on the east side of the island. The principal tunnel, where the tram terminated, is 550 feet higher than the beach and includes somewhat more than 60 feet of crosscuts and adit. Several other openings at slightly lower levels represent about the same amount of labor.

The country rock is greenstone. The main adit was driven in an iron-stained shear zone that strikes $\mathrm{N} .10^{\circ} \mathrm{W}$., dips $70^{\circ} \mathrm{E}$., and ranges from 10 inches to 10 feet in width. This zone extends for considerable distances above and below the tunnel but is not heavily mineralized. The best copper deposits are at the mouth of the tunnel where lenses of solid sulfides are as much as 6 inches thick. Lenses of solid sulfides from 3 to 12 inches thick are exposed in the footwall of the shear zone.

\footnotetext{
${ }^{30}$ Johnson, B: L., op. cit., p. 216.

${ }^{31}$ Johnson, B. L., op. cit:, 'p. 216.

${ }^{32}$ Grant, U. S., and Higgins, D. F., op. cit., p. 68.

as Johnson, B. L., op. cit., p. 216.
} 
The minerals composing the ore bodies are chalcopyrite, chalmersite, pyrrhotite, and quartz. Limonite is present as an alteration product of the iron sulfides. Some ore was shipped to the smelter from this deposit.

\section{OTHER LOCALITIES ON DRIER BAY}

On the south side of the entrance to Northeast Cove are the ruins of mine buildings and a trail that leads to several old tunnels in the steep mountainside. This camp and the tunnels were the property of the Twentieth Century Knight Island Copper Mining Co. The longest tunnel, probably several hundred feet long, is 400 feet above the water and was driven in a vertical shear zone in coarsely granular greenstone. The shear zone strikes N. $15^{\circ} \mathrm{E}$. and is about 3 feet wide. Samples of the ore show mainly the iron sulfides but may contain a little chalcopyrite or chalmersite.

Barnes Cove is a small inlet on the southeast side of Drier Bay near its eastern end. At the head of the cove are the remains of buildings that were the property of the Knights Island Copper Mining Co. One-fourth mile southeast of the cove and 300 feet above it are two tunnels in dark greenish-gray greenstone. The upper tunnel is only 15 feet long but the lower one, which was buried in snow and inaccessible when visited, was evidently much longer. Samples of ore show iron and copper sulfides; their source in the tunnels was not identified.

The Mallard group of claims is in a gap in the ridge about $21 / 4$ miles south-southwest of the head of Mallard Bay, and 1,500 feet above it. The exploratory work on the claims includes a shallow shaft and some open-cuts in a shear zone that cuts the greenstone country rock of this locality and probably accounts for the presence of the gap. According to Johnson ${ }^{34}$ the strike of the footwall of the shear zone changes from $\mathrm{N}$. $35^{\circ} \mathrm{E}$. at the south end of the exposures to N. $80^{\circ}$ E. at the north end. The dip is $60^{\circ}$ to $70^{\circ} \mathrm{W}$., and the width probably does not exceed 20 feet. Ore containing 5 percent of copper was reported to have been taken from the shaft. The ore minerals identified are epidote, pyrite, chalcopyrite, and quartz. "No ore is known to have been shipped from this property.

A tunnel was driven in a fault zone in pillow lavas at the south end of Cathead Bay, west of Mallard Bay. The tunnel is more than 50 feet long and trends $\mathrm{S}$. $55^{\circ} \mathrm{E}$., the same direction as the fault zone. The sheared rock is stained with iron hydroxides on the surface and is mineralized with pyrite and probably other sulfides, but not in sufficient quantity to be important.

${ }^{34}$ Johnson, B. L., op. cit., p. 217. 


\section{SNUG HARBOR}

Many years ago a tunnel was driven near the shore of the point of land at the north side of the entrance to Snug Harbor. It lies along a shear zone in much folded and faulted graywacke and slate beds that include some greenstone. The tunnel trends $\mathrm{N} .15^{\circ} \mathrm{W}$. for the first 50 feet and then swings more to the north for an unknown distance.

A maximum width of $21 / 2$ feet of mineralized country rock crops out west of the tunnel. The shear zone has a width of $5 \frac{1}{2}$ feet in places and includes lenses of solid sulfides as much as 12 inches thick. Quartz, epidote, chalcopyrite, and pyrrhotite are the minerals recognized in the outcrop. No work appears to have been done on the property recently, and little besides the excavations remains to suggest that a camp was located here.

\section{HOGAN BAY}

A mining property that was known in early days by the name Happy Jack Mining and Development Co. ${ }^{35}$ is situated on the south side of Hogan Bay near the south end of Knight Island. This property was restaked by the Hogan Bay Copper Co. and may have changed hands again since then. Considerable development work was done by the original owners. Two principal adits, with an aggregate length, including adits and drifts, of more than 600 feet, were driven in mineralized rock at altitudes roughly 250 and 450 feet. Near the beach a third tunnel between 1,100 and 1,200 feet long was driven to intercept the ore bodies disclosed by the upper adits and the outcrop. Apparently it did not find the ore body. The mine was equipped with office, mess hall, bunkhouse, and steam power plant, none of which remain. The boiler for the power plant is said to have been moved to Hogan Bay from Boulder Bay.

The bedrock is chiefly massive bedded graywacke associated with subordinate beds of slate. In places on Hogan Bay a little greenstone crops out. The mineralization took place in fracture zones which now contain quartz, chalcopyrite, sphalerite and pyrrhotite. ${ }^{36}$ About 2 feet of ore was said to have been exposed in the outcrop near the upper tunnels. A small quantity of the ore was mined and shipped to the smelter, and a little was left on the dump.

MUMMY BAY

Two copper prospects of promise were found at the head of Mummy Bay. ${ }^{37}$ They were tested but the exploratory work was not extensive

${ }^{35}$ Grant, U. S. and Higgins, D. F., op. cit., p. 68.

${ }^{36}$ Johnson, B. L., op. cit., p. 220.

${ }^{37}$ Johnson, B. L., op. cit. (662) p. 219. 
on either of them and so far as the writers know was not continued after 1916.

One prospect, formerly known as the Home Camp lode, is near the shore at the head of the north arm of the bay. At this place are a shallow shaft, a short tunnel, and several open-cuts, which were made in a shear zone or zones in fine-grained greenstone associated with slate. The shaft is in mineralized rock in a shear zone 5 feet wide where lenses and disseminated grains of iron and copper sulfides were deposited. Although the ore-bearing rocks are now covered with vegetation, the largest lens noted by Johnson in 1916, when the surface was better exposed, was 10 feet long with a maximum thickness of 10 inches. The mineralized shear zone had been exposed for 165 feet by the open-cuts. The minerals recognized were quartz, pyrrhotite, chalcopyrite, sphalerite, and chalmersite.

A second ore body, covered by a claim called the Minnie, crops out east of the East Arm of Mummy Bay and 700 feet higher than the bay. A tunnel 140 feet long was driven at this place in a mineralized shear zone cutting slate and graywacke beds and greenstone that Johnson states is an intrusive body in the sedimentary beds rather than a surface flow interbedded with them. The sulfide and associated minerals are those common to the district: Chalcopyrite, sphalerite, pyrrhotite, and quartz. Here, as at Latouche, a little secondary native copper is present in the weathered outcrop.

\section{NORTHWESTERN PRINCE WILLIAM SOUND}

The map prepared by Grant and Higgins ${ }^{88}$ to show the distribution of mineral resources on Prince William Sound in 1908 lists 10 copper prospects in the Glacier Island district. This list includes prospects on the adjacent mainland to the north as well as on Glacier Island. Johnson ${ }^{39}$ reported six properties active in 1916 and 1917, but only one or two of these were in the earlier list. Since 1917, little if any work has been done on these claims. One at least was patented, others have since been restaked, and still others are probably open to relocation.

\section{GLACIER ISLAND}

The more important copper claims on Glacier Island are the Portsmouth and Scotia Bell claims belonging to Jens Jensen. (See pl. 6.) They lie south of Finski Bay near the east end of the island; when visited by Johnson in 1917 they were being explored by two principal

\footnotetext{
${ }^{38}$ Grant, U. S. and Higgins, D. F., op. cit., p. 10.

${ }^{89} \mathrm{~J}$ ohnson, B. L., Mining on Prince William Sound, in Mineral Resources of Alaska, 1916 : U. S. Geol. Survey Bull. 662, p. 186, 1918; in Mineral Resources of Alaska, 1917: U. S. Geol. Survey Bull. 692, p. 146, 1919.
}

$8801840-50 \div 3$ 
tunnels driven on a strongly mineralized shear zone in the greenstone country rock. A lower tunnel a little more than half a mile south of Finski Bay and 250 feet above sea level had about 225 feet of workings, including a main drift 150 feet long and several crosscuts. The mineralized part of the shear zone has a width of about $31 / 2$ feet and is traceable for about 60 feet. The principal fracture strikes north and dips steeply west. The ore is in hard, shattered greenstone cemented by quartz. The other minerals of the ore are epidote, pyrite, and chalcopyrite. Ten feet of slightly cupriferous pyrite was reported to have been found in one of the crosscuts.

A second tunnel, at an altitude of 500 feet, was driven 30 feet in a shear zone in the greenstone. At the mouth of the tunnel the shear zone strikes $\mathrm{N} .5^{\circ} \mathrm{W}$. and dips about $65^{\circ}$.W. The mineralized part of the shear zone at the mouth of the tunnel is 5 to 12 inches wide. The face of the tumnel showed 4 feet of shattered greenstone that was cemented by quartz containing chalcopyrite and lesser amounts of other sulfide minerals. A streak of chalcopyrite that has a minimum thickness of 3 inches is exposed along the hanging wall.

\section{CEDAR BAY}

Considerable development work has been done on copper prospects on Cedar Bay, an easterly arm of Wells Bay, which is an inlet of the mainland west of Glacier Island. One of these prospects is on a small cove near the head of the bay, $31 / 2$ miles northeast of the south end of the land mass between Cedar Bay and Granite Bay. The cove is almost shut off from the main bay by islands and affords a good anchorage for small boats.

The country rock of most of Cedar Bay is granite. A 30-foot tunnel with a 10-foot crosscut was driven on a mineralized fault or shear zone about one-fourth mile from the beach. This tunnel is northeast from the point of land on the south side of the entrance to the cove and 270 feet above sea level. About 250 feet nearer the cove and 100 feet lower than the upper tunnel is a second, longer tunnel which was intended to intersect the mineralized zone at a lower level but which was abandoned before the zone was reached.

The shear zone at the upper tunnel ranges from 8 to 10 feet in width, is vertical, and strikes north. In places the granite is brecciated and healed with quartz accompanied by metallic minerals. The sulfide minerals in decreasing order of abundance are pyrite, sphalerite, and a little chalcopyrite and covellite. The largest lens of pyrite exposed in the tunnel is 8 inches thick and between 3 and 4 feet long. Veinlets of sphalerite exceed half an inch in thickness. The sulfide minerals are much more abundant on the dump than in the tunnel. 
This deposit has been looked on as a possible source of zinc rather than copper, but from the exposures in the tunnel and assays of ore from the dump it is doubtful that the quantity of zinc is large enough to make the ore valuable for zinc alone. At one time the mineralized zone was covered by six claims arranged end to end and extending north-south. East of them is a small lake, which is drained by a creek that empties into Cedar Bay and may furnish water power for any future mining operations. Ownership of the claims has changed several times. In June 1943 the claims were relocated.

It is reported that a low-grade copper deposit was found about 1 mile north of the deposit just described, possibly on the continuation of the same shear zone.

\section{OTHER PROSPECTS}

Mineralized areas of sulfides of copper and other metals are found at many places in the mainland area between Long Bay and Port Wells. Some of the mineralized bodies have been explored more or less thoroughly, but, either because they are too low grade or inaccessible, have not produced any ore. The prospects include a copper deposit on Siwash Bay on the west side of Unakwik Inlet and two in the Miners Bay area on the east side. Considerable work has been done on claims at the head of Wells Bay and on Long Bay. 



\section{N DEX}

A

Addison Powell property

Alaska Commercial Co.

Alaska Copper Corp.

All-American lode

Bald Eagle claim

Barnes Cove

Barrack ore body

Bay of Isles area.

Beatson Copper Co. (Kennecott)

Beatson-Bonanza mine.

Blackbird ore body

Blakney property.

Bottle Creek.

Boulder Bay area

Burke and Steele property

\section{o}

Cathead Bay

Cedar Bay area

Chenega ore body

64.-...- 64

Copper Coin group claims........... 72-73

Copper Crown claims....................... 54

Copper mining in the area, history of ....... 50-51

Copper Mountain ........................ 58,60

Cordova........................................ 49,62

Crown Copper Co

$\mathrm{D}$

Dickey, W. A

Dickey Copper $\mathrm{Co}_{\text {. }}$

Dolan and Rystrom

Drier Bay area.

Duchess claim

Duke claim - 62

Elgin claim

Ellamar area.

Ellamar Mining Co $50,55-56 ; \mathrm{pl}, 4$

$\mathrm{F}$

Fidalgo-Alaska Copper Co. $51,60-61$ Fidalgo Mining Co. property $61-62 ; \mathrm{pl} .4$ Finski Bay.

G

Galena Bay area $53-54 ;$ pl. 4 Galena Bay Mining Co 53,54

Geology of the area, general features ........ 49-50 Girdwood ore body

64

Glacier Island area $75-76 ;$ pl. 6

Gladhaugh, M. O

Gleason. See Mason and Gleason claims.

Granby Consolidated Mining, Smelting \& Power Co., Ltd.

\section{$\mathrm{H}$}

Page

Happy Jack Mining and Development $\mathrm{C}_{0} \ldots . \mathbf{7 4}$ Hemple Copper Co

Herring Bay area......................... 69; pl. 5

Hogan Bay area....................... 74; pl. 5

Hogan Bay Copper Co . . . . . ............ 74; pl. 5

Home Camp lode prospect................. 75

Horseshoe Bay area.................... 65-66; pl. 5

Hubbard-Elliott $\mathrm{Co}_{\ldots} \ldots \ldots \ldots \ldots$

\section{I}

Irish Cove

\section{J}

Jack Bay area. . . . . . . . . . . . . . . . . . . . ... 53; pl. 4

Jensen, Jens................................... 75

Johnson, B. L., quoted ................... 67-68, 72

Jonesy group claims........................ 70-71

Jumbo lode................................. 51-52

$\mathrm{K}$

Kennecott Copper Corp.................. 50, 63

Keystone claim ........................... 57

Knight Island . . ................. 48, 50, 63,67-68; pl. 5

Knight Island Consolidated Copper $\mathrm{Co}_{\text {. . . . . }} \quad 70$

Knights Island Alaska Copper Co............ 71-72

Knights Island Mining and Development Co. $\quad 68$

\section{$\mathrm{L}$}

Ladysmith ore body. Landlocked Bay area............ 48, 56-59; pl. 4

Landlocked Bay Copper ..................... 57-58

Latouche Island . . . ................. 50,63-67; pl. 5

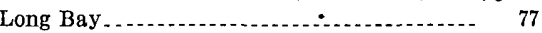

Louis Bay area. . . . . . . . . . . . . . . . . $68-69 ;$ pl. 5

Lowe River . .............................. 52

Mallard group claims.................... 73

Mason and Gleason claims................... 62

Midas Copper Co........................ 51

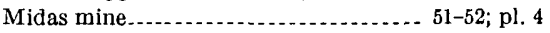

Minerals:

Arsenopyrite . . . . . . . . . . . . . 53, 68

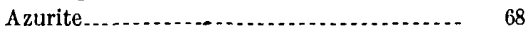

Calcite ................. 54, 56, 68

Chalcocite........................................ 68

Chalcopyrite.................. 52, 53,54, 55, 56.58, $59,61,62,65,66,69,70,71,72,73,74,75,76$

Chalmersite.......... 56, 58, $65,68,70,71,72,73,75$ Chlorite .............. 68, 69, 70

Copper, native......................... 68, 75, 76

Covellite................................... 68,76

Epidote . . . . . . . $68,69,70,71,73,74,76$

Galena........................... 49, 53, 56, 65, 68

Gold ..................... 49, 56, 62,65.68

Limonite and other iron oxides. . . . . . . . 52,69 73

51 Malachite................................... 5268 
Minerals-Continued

Melaconite.

Pyrite.

$52,53,54,56$

$59,61,62,65,66,68,69,70,71,73,76$

Pyrrhotite .................... 52, 53, 54, 55, 56, $58,61,62,65,66,68,69,70,71,72,73,74,75$

Quartz $53,54,56,65,68,69,70,71,72,73,74,75,76$

Silver. $52,65,68$

Sphalerite

$53,54,56,58,62,65,68,69,70,72,74,75,76$

Zinc (see also under sphalerite)

Miners Bay.

Minnie claim lode

Monarch claim.

Montezuma claim

Montgomery Bay area

Mummy Bay area. $66-67 ; \mathrm{pl} .5$ $74-75 ; \mathrm{pl} .4$

$\mathrm{N}$

Nellie group claims

Northeast Cove area, location

\section{0}

Orca Bay area $62-63$

Orca group, rocks

\section{$\mathrm{P}$}

Pandora group claims

Peabody Alaska Copper Corp

Peterson, $\mathrm{C}$

Point Helen.

Port Fidalgo.

Port Valdez area.

Port Wells area, prospects

Portsmouth claim.

Powell property

\section{$\cdot \mathrm{R}$}

Reynolds-Alaska Development Co... Rock types:

Age of

Intrusive

Lamprophyre dike

Limestone.

Orca group

\section{1}

73

53

55

67

4

$.48,60-62 ;$ pl. 4 $-53 ; \mathrm{pl}, 4$
77 75-76; pl. 6

52

V
$54,59,65$ Vi

Page

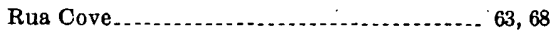

Russell Ball Copper Co ................... 72

Rystrom. See Dolan and Rystrom.

\section{S}

Schlosser property .......................... 60

Scotis Bell claim ........................ 75-76; pl. 6

Seattle-Alaska Copper $\mathrm{Co}_{\ldots} \ldots \ldots \ldots$

Sheep Run claim................................ 54

Siwash Bay ................................. 77

Snug Harbor area, location. ........... 67, 74; pl. 5

Solomon Gulch............................... 51

Standard Copper Mines Co............. 57, 58-59

Starvation claim........................... 54

Steele. See Burke and Steele property.

Structure:

Attitude of shear zones.................... 52 , $53,54,56,59,61,70,71,72,73,74,76$

Beatson fault....... 65

Fault at Ellamar. ...................... 56

Landlocked Bay overthrust......... 54, 56, 57, 60 Sulphide Gulch prospect................ $52-54 ;$ pl. 4

Sunnyside claim ..................... 54

Tatitlek Narrows........................... 55

Threeman Mining Co . . . . . . . . . . . . 51, 57; pl. 4

Twentieth Century Knight Island Copper Mining Co. property, features.... 73

$\mathrm{U}$

Unakwik Inlet

V

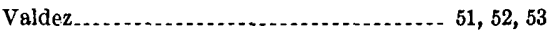

Vesuvius claim................................. 54

Vesuvius Valley...................... 53, 54

Virgin Bay, location............ 55 ; pl. 4

$\mathbf{w}$

Wallace, McPherson, and Valentine......... 69

Wells Bay ..................................... 77

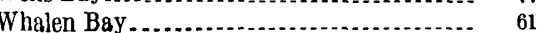

Wilson Bay area........................ 66; pl. 5

Winchester claim.......................... 61 